\title{
REGELEN VAN KLANKVERBINDING IN 'T OUDJAVAANSCH.
}

DOOR

H. K E R N.

Wanneer taalklanken, hetzij als bestanddeelen van een woord of als sluit- of beginletter van twee op malkaar volgende woorden, met elkaar in aanraking komen, kunnen ze door wederkeerigen invloed, of door versnelling der uitspraak, of ook ten gevolge eener natuurlijke neiging bij sprekenden om het zich gemakkelijk te maken, zekere veranderingen ondergaan, die onder bepaalde regelen kunnen gebracht worden. Zulke regelen van klankverbinding in woord of volzin, van Sandhi, zooals de term in de Indische spraakkunst luidt, moeten in meerdere of mindere mate in elke spreektaal voorkomen, doch ze worden meestal slechts ten deele in geschrifte toegepast. Terwijl bijv. in 't Sanskrit alle klankveranderingen bij Sandhi met groote nauwkeurigheid in de geschreven taal worden uitgedrukt; terwijl ook in het Grieksch, vooral het oudere, de Sandhi in den geschreven vorm der taal tot zijn recht komt, pleegt men in onze eigene taal, waarvan de Sandhi-regelen even talrijk en ingewikkeld zijn als in 't Sanskrit, de klankveranderingen slechts gedeeltelijk voor 't oog af te beelden; de overige moet ieder lezer met behulp zijner kennis der spreektaal zelf toepassen.

Het Oudjavaansch, welks stelsel van schrift zoo geheel en al op de leest van ' $t$. Indische geschoeid is, volgt zijn voorbeeld ook daarin dat het alle veranderingen door 't samenkomen van klanken veroorzakkt in de geschreven taal tracht uit te drukken. Er is zelfs reden om te vermoeden dat de schrijftrant der eigenlijk gezegde letterkundige gewrochten de Sandhiregelen der Sanskritspraakkunst slaafscher volyde dan door het heerschend taalgebruik gewettigd was. In hoeverre zulks het geval was, zal bij de behandeling der feiten een punt van onderzoek uitmaken. Het bestaan echter van bepaalde zgn. welluidendheids5e Volgr IV. 
regelen in de gesproken taal valt niet in twijfel te trekken, want de meest belangrijke er van vindt men terug in andere Maleisch-Polynesische talen die nooit onder Indischen invloed gestaan hebben. Daarenboven bezit het Oudjavaansch verscheidene klankveranderingen die aan het Sanskrit vreemd zijn.

Ten einde later niet telkens in herhalingen te vervallen, moet ik hier eene algemeene opmerking maken, nl. deze, dat de spelling, zooals wij die zelfs in de oudste oorkonden aantreffen, klaarblijkelijk eene historische was, d. i. niet meer in allen deele de gelijktijdige uitspraak nauwkeurig weêrgaf. Het lijdt geen twijfel, of er is eenmaal een tijdperk geweest dat men algemeen uitsprak rĕngö, tût, $i k \hat{u}$, lěbû, râh, rât, kapûjân, en dgl., doch dat tijdperk ging den datum der oudste ons bekende oorkonden der 9de eeuw vooraf. Wanneer men in één en hetzelfde stuk nu eens kabaih (eigenlijk gespeld kabâih), dan weêr kabeh geschreven ziet, dan zal niemand aarzelen de gevolgtrekking te maken, dat de schrijver zelf uitsprak $\mathrm{kabeh}$, en dat het kabaih van zijne hand eene historische spelling vertegenwoordigt. Waar in één en hetzelfde stuk een oudere en een jongere vorm voorkomen, daar is alleen de jongere beslissend voor de uitspraak van den schrijver en bewijst de oudere hoegenaamd niets, om de eenvoudige reden dat een menschenkind wel kan weten hoe men vó́r zijn tijd placht te schrijven, maar niet kan vooruitzien hoe men later zal spreken of schrijven. Natuurlijk is de mogelijkheid niet uitgesloten, dat er tot op zekere hoogte een klein verschil in uitspraak tezelfder tijd in verschillende kringen gehoord werd. Het is bijv. zeer wel denkbaar, dat de dichters, die nu eens tût, râh, dan weêr $t u t, r a h$ bezigden, leefden in een tijd, toen de oudere uitspraak ( $t \hat{t} t, r a ̂ t)$ nog niet geheel uitgestorven, en de nieuwere $(\mathrm{tut}, \mathrm{rat})$ nog niet algemeen doorgedrongen was - eenmaal heeft er zulk een tijdperk van overgang bestaan - , maar het is evengoed mogelijk, dat die dichters, zelven gewoonlijk de jongere uitspraak volgende, den hun bekenden verouderden vorm bezigden, waar deze hun te stade kwam ${ }^{1}$.

1 Wanneer de hedendaagsche Javanen eenen klank meer dan gewoonlijk rekken, dan heeft dit niets gemeen met de etymologisch lange klinkers der oude taal. Zulk eene rekking berust op rhetorische gronden, en is te vergelijken met wat men in 't Skr. noemt pluta. De pluta is zeer gewoon ook in 't Nederlandsch, bijv. als iemand met groote verbazing vraagt $\mathrm{z}$ oo ? 


\section{HOOFDSTUK I.}

SANDHI IN EEN Woord (inwendige Sandhi).

\section{$\S 1$. Klinker met klinker.}

A met a wordt â. Dus mâwak, kâwakan, pakâwak, van a wak met de voorvoegsels ma, ka, paka; mângĕn, kângĕn van angĕn; pâjar, pinâjarakĕn van ajar; kâri van ka met ari. Uit manghana, sumiddha met akĕn wordt manghanâkĕn, sumiddhâkĕn; uit inanugraha + an wordt in anugrahân; van patapa, kabanyâga met an komt patapân, $\mathrm{kabany}$ ânân. Zoo is râma (vader) ontstaan uit ra + ama, râri uit $\mathrm{ra}+\mathrm{ari}$. Zelfs een $a-a$, ontstaan door 't uitvallen van den gutturalen triller, trekt samen in $\hat{a}$; bijv. râh uit ra'ah; kĕlâ uit kĕla'a (Bisaya, Tagalog laga); sâtus uit sa-'atus.

Men kan verzekerd wezen, dat deze regel eenmaal zonder uitzondering gegolden heeft: Ontmoeten wij desniettegenstaande in de ons bekende teksten zooveel afwijkingen, dan zijn deze deels toe te schrijven aan geleidelijk klankverloop, deels verklaarbaar als schijnbare uitzonderingen. Tot de eerste categorie behooren schrijfwijzen als rat, rah; rama, rari, sanak e. dgl., welke herhaaldelijk voorkomen in geschriften die evenzeer de $\hat{a}$ van Skr. woorden af en toe vervangen door de korte. Tot de tweede categorie meen ik te moeten brengen woorden als karâman, kaiçwaryyan, patapan; kari voor kâri, achtergebleven; manghanakĕn. De drie eerste voorbeelden toch behoeven niet noodzakelijk het aanhechtsel a $\mathrm{n}$ te bevatten; immers naast an was er een gelijkwaardig ĕn in gebruik (vgl. Bug. ěng = ang); bijv. k alěpa sěn, verlossing (Arj. Wiw. $56,66)$ ! kadadin; karatun. De $k$ (kĕ) voor $\mathrm{ka}$ in kari, geheel in overeenstemming met het nieuwere spraakgebruik, is eerder aan klankverloop te wijten dan als een schijnuitzondering te beschouwen; want dat de oudste vorm van het voorvoegsel ka geweest is, blijkt duidelijk uit de hiermede afgeleide vormen van stammen wier stam met $i$ of $u$ begint. Wij mogen ons niet beroepen op woorden als kĕnâ, kĕnoh, kĕlâ e. dgl., want hierin heeft de $\mathrm{k} \breve{~ e e n ~ a n d e r e ~ f u n c t i e ~ d a n ~ i n ~} \mathrm{kari}$ voor $\mathrm{k}$ âri. Wat het aanhechtsel $\mathrm{k}$ ĕn met de waarde van akĕn aangaat, pleit voor den hoogen ouderdom er van de overeenstemming tusschen Sundaneesch kön, dichterlijk. Jav, kĕn en Bataksch hon (uit kĕn), Mal. kan. 
De behandeling van gevallen waarin de lange klinker op andere wijze dan door samenvloeiing ontstaan is, blijft hier uitgesloten.

Onder de verwante talen komen het Bug. en Mak. in zooverre met het $\mathrm{O}$. J. overeen, dat zij $a+a$ in $\hat{a}$ plegen samen te trekken; bijv. Bug. tawâng=tawa-ang; Mak. kanâng =kana-ang; boy âng = boya-ang (Matthes Boeg. Spr. § 63; Mak. Spr. §179). In het Fidjisch kan een op $a$ uitgaande stam zoogenaamd "definitivepassive" worden doordat de eindklinker den klemtoon tot zich trekt en gerekt wordt uilgesproken; dus tára wordt ta râ (Hazlewood Gramm. p. 39 ; vgl. p. 5). De reden is dezelfde als in 't Mak. en Bug. dewijl tarâ ontstaan is uit tára met aanhechtsel an.

Eene â gevolgd door a geeft $\hat{\mathbf{a}}$; bijv. kapûjân, van den stam $p \hat{u} j a ̂$.

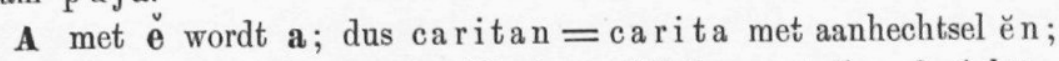
warṇṇan = warṇṇa + ĕn. De lange klinker met $е$ geeft $a$; bịjv. kĕlâ met ĕn wordt kĕlân.

A met $\mathbf{i}$ wordt $\boldsymbol{e}$. Bijv. a $+\mathrm{inak}=\mathrm{enak} ; \mathrm{ma}+\mathrm{irang}=$ merang; $k a+i p i=k e p i ; s a+i l w a n=s e l w a n$. Dezelfde regel geldt ook in 't Ibanag; bijv. ma +ilug wordt melug (gespeld $\mathrm{m} æ \mathrm{lug}$ ); volgt er op de $i$ oorspronkelijk een klinker, dan wordt als overgangsletter tusschen de zoo ontstane $e$ en den volgenden klinker eene $y$ ingeschoven; bijv. $\mathrm{ka}+\mathrm{i}+\mathrm{ul} \mathrm{u}$ a n wordt $\mathrm{k}$ e y u l u a n. Ook in het Malegasi en het Sideïsch-Formosaansch moet eertijds dezelfde regel als in het $\mathrm{O}$. $\mathrm{J}$. en het Ibanag van kracht geweest zijn; een spoor daarvan is overgebleven o. a. in het Maleg. woord reny, Sid. rena, moeder, $=0$. J. rẹna, uit ra + in a. In beide talen is deze regel echter verouderd, evenals in 't $\mathrm{N}$. Javaansch. Vormen als N. Jav. keli e. dgl. zijn natuurlijk in hun geheel overgegaan en in strijd met de hedendaagsche klankwet, volgens

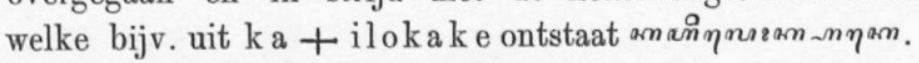

A met $\mathbf{u}$ wordt o. Dus $\mathrm{ma}+\mathrm{utus}=$ motus; $\mathrm{a}+\mathrm{ulih}=$ olih;ka+untal =kontal; sa +ujar = sojar; pa+ulah = polah. Geheel hetzelfde vinden we terug in 't Ibanag; bijv. $\mathrm{ka}+\mathrm{uman}=\mathrm{koman} ; \mathrm{ma}+\mathrm{uma}=\mathrm{moma} ; \mathrm{pa}+\mathrm{ulug}=$ polug. Wat N. Jav. woorden als ᄁameanny e. dgl. betreft, is van toepassing hetgeen zooeven van de $e$ uit $a+i$ gezegd is.

A met ai levert ai op; $\mathrm{ka}+$ aiçwaryyan $=k a i c ̧ w a r y y a n$.

Uit ö met a wordt gewoonlijk wa. Dus rumĕngö + a wordt rum ĕngwa; karĕngö met an: karĕngwan; pir ĕngö met akĕn geeft pirĕngwakĕn; kasĕnö $+a n=k$ asĕnwan. Een 
vorm als pirĕngökĕn in KO. II is te verklaren als bestaande uit pirĕngö en het aanhechtsel kĕn voor a k ĕn; vgl. het boven bij a opgemerkte.

In afwijking van den hier gegeven regel schrijven de oorkonden hier en daar ěa voor wa; dus tĕas, p ěar, inangsĕan, in as ěan, mangasĕakan, hamĕas. Dat deze spelling een antiquiteit was, blijkt voldoende uit het feit, dat men in dezelfde oorkonden nooit běat, steeds bwat, kabwat e. dgl. geschreven vindt. Eene andere afwijking vertoont zich hier en daar, waar instede van het te verwachten wa te lezen staat yĕ, yö, of misschien wĕ, wö, want de Pasangans voor $y$ en $w$ lijken veel op elkaar. Zoo heeft KO. V eenmaal Janatyĕsan of, mogelijk bedoeld otwĕsan; een andermaal Janatwasan: in VII, 6 ziet men rĕngyökĕn; daarentegen in Holle's oorkonde van Çaka 782 duidelijk rĕngwökĕn. In het nog onuitgegeven vervolg van KO. XXVIII komt herhaalde malen K aty ĕng in stede van Katwang, am qains, voor. Hoe deze zonderlinge schrijfwijze, te verklaren? Het is niet aan te nemen, dat janatwasan en janaty ěsan te gelijkertijd nawwkeurig de bestaande uitspraak weergeven; wel is het mogelijk, dat geen van beide het doet. Let men nu op de omstandigheid dat in de vrij oude oorkonde van Caka 853 (No. VII) doja staat voor Skr. dhwaja, en katĕmon voor katĕmwan; dan lijdt het geen twijfel dat men om 900 AD. reeds gelijk in 't N. Jav. sprak $o$, maar nog schreef wa, behalve in enkele gevallen, waar de natuur boven de leer ging. Aangezien KO. V, waarin we janatwasan gespeld vinden, eene eeuw jonger is dan No. VIJ, volgt a fortiori dat de spelling twasan voorstelt eene uitspraak tosan. Hicruit volgt verder dat ook tyĕsan, of

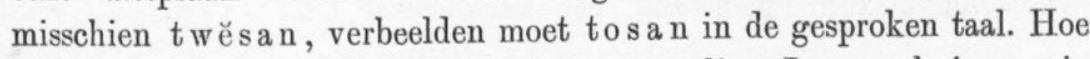
kan dit? Eenvoudig doordat in het toenmalige Javaansch in menig woord de oudere Pĕpět in de spelling bewaard bleef, terwijl men het toch met $o$ uitsprak. Vergelijkt men het oudere rĕng ö, göng of gĕng, e. dgl. met het hedendaagsche rungu, gung, dan ziet men dat er een schakel in de ontwikkeling der klanken ontbreekt: die schakel wordt gevormd door de $o$. Tusschen rĕngö en rungu ligt er dus een rongo, en er is zonder twijfel een tijdperk geweest, bijv. tusschen 900 en $1200 \mathrm{AD}$, dat men in eene menigte woorden het oude Pěpětteeken in schrift behoudende, daaraan de uitspraak verbond van $o$. De werkelijke Pĕpĕt heeft in de nieuwe taal in te veel gevallen stand gehouden dan dat de Javanen er toe hebben kunnen komen de Pěpĕt als teeken voor $o$ te bezigen, maar wat in 
het Javaansch niet geschied is en nauwelijks geschieden kon, heeft plaats gehad in het Tobasch. Deze taal, wier geheele spelstelsel zeer ouderwetsch is, zoodat zij bijv. kĕn schrijft, maar hon uitspreekt, kent geen ander teeken meer voor de $o$ dan de Pĕpĕt. De overgang van den klank der Pĕpĕt in dien van $o$ moet dus plaats gehad hebben na de vaststelling der nog bestaande Tobasche spelling. Kortom ty ěsan werd uitgesproken als to san; k a tyĕng als k at ong; rĕngw ök ĕn als rongòk ĕn. De $w$ in het laatste is een overblijfsel van de oudere en eenmaal phonetisch juiste schrijfwijze rĕng w a k ĕn, doch is even misplaatst als bijv. de $p$ in den Franschen naam Nep ve u, waarin de $p$ haar aanwezigheid te danken heeft aan de misplaatste neiging van een klerk, die toonen wilde te weten dat het Latijnsche $\mathrm{nepos}$ eene $p$ heeft en dat neveu uit nepos ontstaan is. De $y$ in J anatyĕsan e. dgl., zoo die werkelijk bedoeld is, moet haar oorsprong hebben in een verkeerd gelezen Pasangan $w$. Hoe men těas, pĕar e. dgl. verouderde vormen uitsprak, laat zich moeielijk met zekerheid bepalen; vermoedelijk zeide men toas, of anders tos.

Eene $\ddot{0}$ gevolgd door ĕn blijft onveranderd. Derhalve rĕngö +ĕn geeft rĕng ön.

De korte en lange $\mathbf{i}$ gaan voor ongelijkslachtige klinkers (behalve $\check{e}$, welke nauwelijks als een klinker mag gelden, al kan zich licht een volle klinker er uit ontwikkelen) over in $y$. Bijv. syapa uit si en apa; tinalyan uit tinali en an; walian uit wali en an; mangajya uit mangaji en a; arabya uitarabi en a; wuryyan 1 uit wuri en an; kastryanya uit kastrî en anya. De spelling kastrîanya in KO. VII zal wel door de etymologie veroorzaakt zijn; men zou eer verwachten kastriyanya, want na twee of meer medeklinkers is iy natuurlijker dan $y$. In KO. V leest men dan ook anulwîyakĕn, uit anulwi, bijvorm van anulwy en akĕn; de lange $\hat{\imath}$ is foutief, doch verklaarbaar, omdat het gevoel voor 't onderscheid in quantiteit der klinkers reeds ten tijde der oudste ons bekende stukken tamelijk verstompt was. Voorbeelden van $i$ vóór $u$ zijn: dyun, Ibanag jun (met Fransche j) voor diun, gewestelijken bijvorm van duin, Bisaya dihiun; dyus voor dius, en dit voor di'us, Mal. dirus, Bis. digus; wangkyul, N. Jav. craminy; hyu, vgl. Dayaksch en Niasch hiu, Sumbasch iyu, Bis.

1 De verdubbeling van medeklinkers en halfvocalen achter eene $r$ mist allen redelijken grond en geschiedt louter in navolging van eene bekende Indische schrijfwijze. 
ihu, Arusch dju, Fidji nggio, Maleg. akio, Mal. hiyau. De $y$ moet als een zuivere halfklinker uitgesproken zijn, gelijk nog heden ten dage in 't Javaansch geschiedt. Feitelijk is deze halfklinker niets anders dan een in tijdmaat gehalveerde korte $i$; wordt de $y$ nog meer verkort, dan verkrijgt men den klank der Russische jer', die men gelijk kan stellen met $\frac{1}{2} y=\frac{1}{4} i$. Zulk een jer', - die hier met' zal aangeduid worden - als verdere verzwakking van $y$, is naar alle waarschijnlijkheid in enkele woorden hoorbaar geweest vóórdat hij geheel wegviel. Bijv. tusschen syapa en het nieuwere as as ligt, theoretisch, s'a pa. Op dezelfde wijze meen ik te moeten verklaren zulke woorden in het Ibanag als sakan $=\mathrm{si}+\mathrm{akan}$; $\mathrm{sam}=$ Bis. siám, Tag. siyam; sa, aan hem, aan haar, $=\mathrm{Sa}-$ ngirsch sia, siya; san $=$ sian, buik, waarvan sinian; vgl. Bis. tyán, Tag., Tondano, Tonsea, Tonsawang, Ponosakan tiyan, Mongondou siyan, Bentenan tjiyan, Mal. tiyan. Ook in het N. Jav. aqa is is de halfklinker spoorloos verdwenen; daarentegen heeft hij zijnen invloed doen gelden in agan , welks as natuurlijk ontstaan is door mouilleering der $d$; nog een stap verder in dezelfde richting heeft het bovenaangehaalde Ibanagsche jun gedaan, dat tot agan staat in dezelfde verhouding als bijv. het Fransche jour tot het Italiaansche giorno. De overgang van $i$ vóór eenen ongelijkslachtigen klinker in $y$ is een gewoon verschijnsel ook in het Bis. en Tag.; bijv. Bis. dyo= Sangirsch dio; Bis. ty an, doch Tag. tiyan; daarentegen Tag. bagyó, in afwijking van Bis. bágio; Bis. sugyut, sogyot; een vaste regel is niet te ontdekken. In het Sangirsch treft men naast dio aan do. De $d$ van dit laatste is op geheel andere wijze ontstaan dan in 't Jav. dus; het is trouwens een andere letter, een linguaal, terwijl de Jav. $d$ interdentaal is. De $d$ van do is ontstaan uit de palatale $\mathrm{dj}$, evenals bijv. in gaheda, kerk, uit gahedja; herleidt men dus Sangirsch do tot den ouderen vorm, dan ontwaart men, dat ook in 't Sangirsch de $i$ voor $o$ in den half klinker kon overgaan; uit d y werd verder dj, en hieruit ten slotte $d$. Sang. do beantwoordt dus rechtstreeks aan Bis. dyo, is eene regelmatige ontwikkeling er van, terwijl met dio te vergelijken is het Bis. diot.

I gevolgd door ĕn wordt in; bijv. wĕlin uit wĕli + ĕn; k adadin uit $\mathrm{kadadi}+$ ĕn.

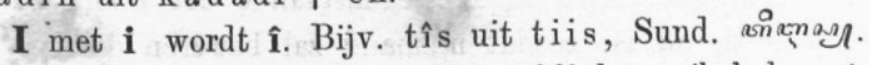

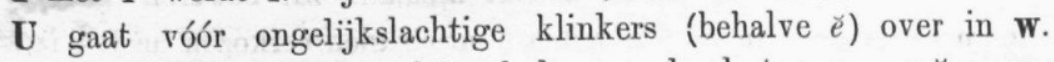
Dus gaat ua over in wa; bijv. lakwan, kaḍatwan, an ĕmwa, 
rĕmpwa, kubwan, wanwa, wwang, kahaywakĕn. In de oorkonden komt behalve wa ook dikwijls ua voor, om te zwijgen van uwa, welk laatste eene andere uitspraak vertegenwoordigt en dan ook in de nieuwere taal onveranderd blijft, bijv. in muwah, gars; sowang (uit sa + uwang), qaneas; daarentegen levert ua $=\mathrm{wa}$ in 't $\mathrm{N}$. Jav. o op. Schrijfwijzen als wanwa, kapwa, tirwan, wwang zijn, in de oorkonden, minder gewoon dan wanua enz. Hoewel nu ua ontwijfelbaar ouder is dan wa, zou men verkeerd doen de gevolgtrekking te maken, dat in den tijd der Oorkonden nog anders werd uitgesproken dan wa of $o$. Dat het onderscheid tusschen ua en wa ten tijde der Oorkouden louter graphisch was, blijkt voldoende uit het feit, dat wij bijv. in KO. V. op denzelfden regel muang en mwang lezen: in No. XXII muang, maarkubwan, kahaywakna, kulwan. Let men er op dat in een der oudste stukken, No. VII, van 853 Çaka zelfs w a reeds eene verouderde spelling vertegenwoordigt, zooals blijkt uit de in dat stuk voorkomende woorden d oja voor Skr. dhwaja, katĕmon, mangulon; dan is het niet aan te nemen, dat in de slechts twaalf jaren oudere oorkonde No. I de spelling ua nauwkeurig de toenmalige uitspraak af beeldt. Fr heerscht in een taalgebied voorzeker altoos zekere verscheidenheid in de uitspraak der woorden; het is dus mogelijk dat men op de eene plaats nog wa zeide, terwijl op eene andere de uitspraak $o$ was doorgedrongen, doch verder mag men niet gaan. Diezelfde stukken toch die $\mathrm{u}$ a schrijgen, plegen tevens ya, en niet $\mathrm{i} a$, te spellen. Het eene rijmt niet met het andere. Van waar nu het verschijnsel, dat men wel de $y$ geschikt oordeelde om den klank van eenen echten halfklinker aan te duiden en de $w$ niet, zoodat men $u$ verkoos? De reden is $\mathrm{m}$. i. deze, dat in de spelling dier stukken welke wuang e. dgl. plegen te schrijven, de door een medeklinker voorafgegane $w$ den klank $b$ uitdrukt, in navolging vermoedelijk van eene niet ongewone Indische uitspraak. In KO. I wordt geregeld $\mathrm{mw}$, $\mathrm{rbw}$ gespeld om $\mathrm{mb}, \mathrm{rbb}$ voor te stellen; in dat stelsel zou de spelling $\mathrm{mwang}$ uit te spreken zijn als mbang of als měwang; om dit te voorkomen nam men de toevlucht tot $u$. Geheel hetzelfde beginsel vindt men terug in de op Spaansche leest geschoeide spelling der Filippijnsche talen. Diensvolgens schrijft men in het Bis. en Tag. diuata of dioata, in plaats van diwata, niettegenstaande het woord aan 't Skr. dewatâ ontleend is, zoodat niemand zal beweren dat hier de $u$ ouder is dan de $w$. De reden waarom men verkozen heeft diuata, dioata te schrijven, is niet ver te zoeken: het Spaansch kent geen 
halfklinker $w$; daarom zou een Spanjaard divata licht gaan uitspreken als dibata, en in geen geval als diwata. Uit $\mathbf{u}-\vdash \mathbf{i}$ wordt ò wi, onverschillig of er tusschen beide eenmaal een medeklinker gestaan heeft of niet; bijv. rwi, uit ouder ru'i, Mal. duri, Tag. dugi; lwir; ò uy, bijv. apuy, tuluy, tamuy, waluy. Deze laatsten hebben evenwel als bijvorm apwi, in Marapwi; tulwi, tamwi, walwi. De grondvorm, waarvan men in 't O. Jav. moet nitgaan is tamui, enz., en niet tamuy, zooals men mag opmaken uit het Dayaksche tamuäi, Bataksch tamawe, die zelfs eenen tweeklank achter de $u(o)$ vertoonen, dus een nog volleren klank dun de Jav. $i$, terwijl de $y$ eene verminking der $i$ is. Bij nog verdere verkorting gaat ook de $y$ te loor. Door een regelmatig verloop zal uit tamuai ontstaan tamué, hieruit tamui, dan tamuy, voorts tam a', eindelijk cmøg, de hedendaagsche vorm. Naast on of bezitten de Javanen echter ook tami. Aan-

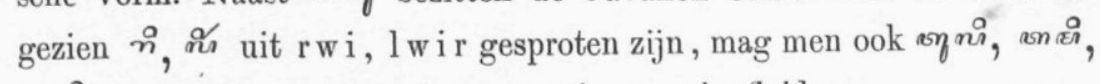
anai regelrecht uit $\mathrm{tulwi}, \mathrm{tamwi}$, apwi afleiden.

De spelling luir in sommige oorkonden vindt hare verklaring in het hierboven opgemerkte; ze dient om te voorkomen, dat men zou uitspreken lěwir of lbir.

U gevolgd door ĕn wordt un; dus tirun=tiru + ĕn; karatun = karatu + ĕn; pituhun = pituhu + ĕn.

$\mathbf{U}+\mathbf{u}$ wordt $\hat{\mathbf{u}}$. Bijv. tût uit tu'ut, Bis., Tag. tugut; wûk uit wu'uk, Mal. buruq; tûr uit tu'ur, Sund. oฑ tuhud. Waar zulk eene $\vec{u}$ verkort voorkomt, is het een teeken van verloop.

De $\boldsymbol{e}$, ontstaan uit den tweeklank ai, vertoont zich vóór eenen klinker in den vorm van ay; anders gezegd, uit $\mathbf{a}+\mathbf{i}$ wordt $\mathbf{e}$, behalve vóór eenen klinker, want in dit geval gaat de $i$ in $y$ over, en daardoor wordt de samensmelting van de twee bestanddeelen des tweeklanks verhinderd. Derhalve gawe, maar gumawaya, gawayakĕn; tambe, maar tambayan; de-nta, maar daya$\mathrm{nta}$. Herhaalde malen ontmoet men zoowel in de gedichten als in de oorkonden gespeld gaway of gawâi voor gawe; balay of balâi voor bale; âir, en dgl. Deze schrijfwijze was historisch, d. i. verouderd. Met zekerheid kan men dit vaststellen voor den tijd van Âir-Langga, zooals de naam gespeld wordt in de staatsstukken onder dezen vorst uitgevaardigd en in den Arjuna-Wiwâha; in de Sanskritinscriptie aan hem gewijd heet hij ondubbelzinnig Er-Langga. 
Reeds meer dan eene eeuw vóór dien Vorst, bijv. in KO. XV, van 804 Çaka, wordt nu eens winâih, dan weêr wineh gespeld; paṇ̣̂̂i en gawâi gaau eendrachtiglijk samen met rake, hetgeen onmogelijk ware, tenzij men $\hat{a} i$ als $e$ uitsprak; de proef op de som levert de vergissing die de schrijver van het stuk begaan heeft in ityâiwamâdi. Met dit al mag men gerust aannemen, dat de oudere en de jongere uitspraak een tijd lang, al was het niet op dezelfde plaats, naast elkaar voortgeleefd hebben, totdat de $e$ volledig zegevierde; in het Sundaneesch en Madureesch heeft zich de tweeklank gehandhaafd, dank zij den overgang van $a i$ in $a y$. Op Maleisch gebied hoort men tegenwoordig ook verscheidenheid van uitspraak. Men hoort dus pakei, zeldzamer pakai, dikwijls pake zeggen; doch lain, main, air of a y ĕr. Betrekkelijk zeldzaam is de verzwakking van $a i$ of latere $e$ vóór een beklemtoonde lettergreep tot $\mathbf{i}$; bijv. gumawyakĕn in KO. V. Nog zeldzamer, en misschien slechts aan afschrijvers te wijten, is een geheel op hedendaagsch standpunt staand deya uit de + a, waarvoor de oudere taal daya zegt.

Eene treffende overeenkomst met het Oudjav., ten opzichte der behandeling van den oorspronkelijken tweeklank, vertoont het hedendaagsche Ibanag. In deze taal schrijft men balay= Oudjav. bale, ouderwets gespeld balay of balâi; ammay = Bis. homay, Bat. omè, enz., doch men spreekt uit: balei, ammei, en vóór een suffix bale; dus bale-mu, in schrift balay-mu, = Oudjav. bale-mu, ouderwets balay-mu (zie de Cuevas, Arte p. 2 en p. 4). Volgt er een klinker, bijv. in balayan, d.i. balay + an, dan geeft de spelling volkomen de uitspraak terug. Ook in enkele andere gevallen gaat ay in 't Ibanag over in den $e$-klank, bijv. in e ka, ga gij! uit ay ka; pen voor payan. Evenzoo gaat in 't Pampanga een oorspronkelijk ay (of ai) voor medeklinkers in $e$ over; bijv. men zegt balebalayan, matematayan; umay, gaan, maar ume ko. Niet geheel vreemd an het Ibanag is ook de verkorting van ay (e) vóór eenen klinker tot $y$, bijv. in piyan, van pay; vgl. zulk een geval als gumawyakĕn. Dezelfde verzwakking van den tweeklank is niet ongewoon in het Tag. en Bis.; bijv. Bis. pasakyan, pasákya, pasákyou, gisákyan, voor pasakay + an, enz.; Tag. bigyan voor bigay + an.

De $\mathbf{0}$, voor zooverre zij uit au ontstaan is, heeft oudtijds natuurlijk de uitspraak van den tweeklank au gehad. Voorbeelden van samensmelting van $\mathbf{a}+\mathbf{u}$ tot $\mathbf{0}$ zijn boven reeds gegeven; in andere wordt de oorsprong van $o$ uit au bewezen door de verwante talen; bijv. hijo, 
groen, Day. hidjau; lod, Mal. láut; ron, Mal. dáun ; ko, Day. ikau. Men zou verwachten, dat zulk een oorspronkelijke tweeklank vóór eenen klinker in aw was overgegaan, doch hiervan heb ik geen enkel voorbeeld aangetroffen; wel daarentegen komt voor het op $\mathrm{N}$. Jav. wijze gevormde paniñjowan (Balin. gespeld paniñjohan) van tiñjo, Sund. ๆanañ. Bij Sandhi in den volzin gaat zulk eene $o$ vóór den beginklinker van een volgend woord over in $w$, waarvan later voorbeelden zullen aangevoerd worden. In het Ibanag wordt au als o uitgesproken in dezelfde gevallen waarin ay als $e$ luidt; bijv. pano-ra van panau (de Cuevas, t. a. p).

De Indische klinkerteekens r en 1 hebben in 't Oudj. in inheemsche woorden de waarde van de medeklinkers $r$ en $l$ gevolgd van eene Pĕpět. Waren die klanken werkelijk klinkers, dan zouden vormen als riněbut, lumĕbur, linĕpas, alle bepaald drielettergrepig, onmogelijk wezen. In verzen wordt de r wel is waar nu en dan als klinker behandeld, zoodat men bijv. a + r pat samentrekt tot ârppat (Bhar. Y. 28); a +r rja tot a rjja; doch zulk eene samentrekking is te beschouwen als eene dichterlijke vrijheid, die men gewettigd achtte door 't voorbeeld van het Sanskrit.

\section{§ 2. MedekLinker MET MedekLinker.}

Nasalen. De nasalen in een woord richten ziç steeds naar het orgaan van den volgenden medeklinker, met deze beperking dat de Anuswâra (Cěcak) vóór sisklanken en $h$ in de gutturale nasaal ng overgaat, zonder twijfel omdat reeds ten tijde der oudste ons bekende stukken de Anuswâra in klank niet van de $n g$ verschilde. Dus schrift men angça, angsö, singha enz., in tegenstelling tot de hedendaagsche spelling inm enz. De sluitende Anuswâra van prefixen wordt $n g$ vóór klinkers, $r$ en $l$ (met inbegrip natuurlijk van ṛ en l); derhalve pangalah uit as en alah; manginum, mangucap, manglawan, mangrĕbut uit en inum, enz. Vóór de $j, d, d h$ blijft zulk een Anuswâra zeer dikwijls behouden,

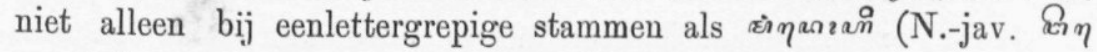

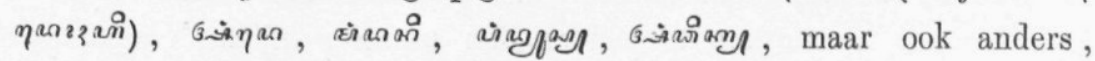

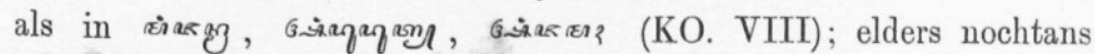
a ñjamah KO. V en VII; a ñjanma BY. 613.1 - Eene d,

1 De met $b$ en $b h$ beginnende stammen worden behandeld alsof de beginletter eene $w$ is, zoodat bijv uit ஜ̇ + bhukti wordt mamukti!, volgens eene vóórhistorische klankwet, die eenmaal algemeen Maleisch-Polynesisch moet geweest zijn. 
welke aan 't begin van een woord $r$ geworden is, behoudt na een nasaal vaak, niet altoos, zijnen oorspronkelijken klank; bijv. susu-ṇ-ḍarâ uit susu + n + rarâ (ouder ḍarâ); roṇ ḍon, een verdubbeld ron (ouder ḍon): umiṇḍhur, van ruhur (ḍulı ur). 1 Afwijkend pingrwa (afwisselend met piṇḍ̂a), rĕngrĕng, waar de nieuwere taal alleen aimm , asm heeft; het omgekeerde zien wij in Karuṇụngan, waarvoor thans am i் jaman. - Bij de verdubbeling van een stam kan de sluitende nasaal zich al of niet richten naar den volgenden medeklinker; dus kingkin of kinkin; tuntung of эì่⿻ . Een vaste regel wordt daarbij niet gevolgd, evenmin als bij de sluitende $n$ van een suffix vóór 't aanhechtsel ku; dus ujarĕn-ku of ujarĕngku: de eerste spelling zal wel louter etymologisch wezen. Naast ping tiga heeft men pintiga.

$V$ erdubbeling. Het verdubbelen van medeklinkers, behalve in ontleende woorden, of in nabootsingen der Indische spelling als bijv. in 't boven vermeld ârppat, wordt in de meeste, vooral dichterlijke, geschriften gaarne vermeden; in andere wordt verdubbeling gebezigd ter aanduiding eener bijzondere uitspraak van den voorgaanden klinker; in weêr andere worden sluitmedeklinkers verdubbeld vóór bepaalde suffixen als an en akĕn, geheel op N.Jav. wijze. In Skr. woorden blijft een dubbele medeklinker dikwijls genoeg behouden, maar wanneer wij bespeuren dat naast elkaar nimitta en nimita e. dgl. geduld worden, dan moeten wij tot het besluit komen, dat de schrijver voor den waren aard der verdubbeling in 't Skr. geen gevoel heeft. In het Skr. toch wordt een dubbele medeklinker bepaaldelijk tweemaal zoolang aangehouden als een enkele, zoodat verwisseling van $t t$ en $t$ onmogelijk is behalve bij verbastering. Het tegenwoordige Javaansch heeft van de echte verdubbeling, zooals die in 't Sanskrit, Italiaansch en Magyaarsch bestaat, geen begrip, en juist daarom maakt het zulk een kwistig gebruik van dubbele letters in geschrift. Van het Nederlandsch, Fransch en de meeste overige talen van Europa geldt hetzelfde. Wanneer wij bakken, liggen, vallen e. dgl. schrijven, dan is het omdat men de eerste lettergreep sluit met eenen medeklinker, hetgeen men niet doen kan zonder den medeklinker iets langer aan te houden dan wanneer hij aan 't begin eener

\footnotetext{
1 Dezelfde regel ook in 't Bulusch; dus renděmmĕn, grv. dĕm; indei = in + rei; vgl. Tag. indi; rĕmděm; evenzoo in 't Day rinděm; vgl. Tag. dimdim, Bal. děmdĕm. Het Iban., bijv. in |laddam (ouder răndăm) stemt overeen met de bovengenoemde talen. Uit Bul. rungdungan en rĕmděm laat zich opmaken dat de nasaal niet altoos geassimileerd wordt, evenmin als in 't 0 . Jav.
} 
lettergreep staat. Spreekt men den medeklinker te kort uit, dan zou tusschen de eerste en tweede lettergreep de adem gestuit worden, zoodat het bàk-en zou worden. Onze dubbele medeklinker wordt dus wel iets langer aangehouden dan de enkele, maar is geen volle dubbele medeklinker. Van daar dat een Nederlander in twijfel kan staan of hij bijv. monnikken dan wel monniken behoort te schrijven. Evenzoo is het in 't Javaansch. Veronderstellen wij hetzelfde ook voor de oudere taal, dan laten zich alle verschijnselen gereedelijk verklaren.

De dubbele medeklinker, met inbegrip der aspiraten, blijft in woorden uit het Skr. overgenomen meestal gespaard; bijv. writta, ruddha. Toch ontbreekt het niet aan voorbeelden dat de dubbele vervangen wordt door een enkelen, zelfs in gedichten; bijv. nimita (Râm. 3) voor nimitta: Kinara voor Kinnara KO. VII. Sommige woorden worden steeds zonder verdubbeling geschreven, als bhaṭâra voor bhațțâra; sĕnâha, sěnaddha voor sannâha, sannaddha. Ook wiku, Prâkrit bhikkhu, wordt onveranderlijk met ééne $k$ geschreven, doch dit woord had misschien reeds in Achterindië dezen vorm aangenomen voordat het door de Javanen werd overgenomen. Wat de geschreven verdubbeling van eenen medeklinker betreft in het bijzonder geval dat een $r$ voorafgaat, als in sarwwa, dharmma, warṇna, deze geschiedt slechts in navolging van eene niet ongewone Indische schrijfwijze. Het volkomen onjaraansche karakter van zulk eene verdubbeling komt helder uit, zoodra men bijv. het ontleende sa rww a vergelijkt met het inheemsche kârwa, karwa, thans an $\eta_{n \text { ? }}$. Hoe weinig het eigenaardige van de Skr. dubbele medeklinkers tot het gewone Javaansche taalgevoel was doorgedrongen, kan men opmaken uit de omstandigheid dat. af en toe een dubbele medeklinker wordt geschreven die niet in het woord behoort, bijv. in boddhi KO. XXIV en elders voor bodhi. In het latere Javaansch, Maleisch en andere verwante talen is de dubbele medeklinker van Skr. woorden ook steeds vereenvoudigd, bijv. \$ి an, Mal. tjita voor citta; Mal. suda voor çuddha; Jav. eৃå Mal. budi, Bis. budhi voor buddhi.

In sommige stukken dient verdubbeling van eenen medeklinker als middel ter aanduiding van den Pěpĕtklank. Deze schrijfwij̄ze wordt doorloopend gevolgd in een Jayapatra van 849 Çaka, uitgegeven door Brandes ${ }^{1}$; de afwijking in een paar woorden, nl. Tabběl of misschien Tabböl (d. i. Tĕbběl met klemtoon op de

1 Tijdschrift Ind. T. L. en Vk. XXXII, 146. 
laatste) en Ha mĕas verklaart zich van zelf, daar het middel der verdubbeling hierin niet kon aangewend worden. De ietwat oudere oorkonde No. 1 van 841 Çaka vertoont dezelfde spelling slechts in een paar woorden, nl. tĕngannan en d̦alamman, in strijd met de andere in dat stuk gevolgde schrijfwijze. Zoo is het ook gesteld met sikappan (d. i. sikĕpan) en paḍamm-apuy in No. 10, en mannang in No. 15. Ofschoon nu deze eigenaardige spelling voor gezegde oorkonden niet als eene phonetische mag beschouwd worden, is het toch zeer wel mogelijk dat ze de uitspraak van een ouder tijdperk zoo niet geheel nauwkeurig weêrgaf, dan toch haar nabijkwam', zoodat wij ook hier wederom een voorbeeld van historische spelling voor ons zouden hebben. In allen gevalle is het opmerkelijk dat het Ibanag vrij regelmatig eene $a$ met daaropvolgenden dubbelen medeklinker vertoont, waar het Javaansch, Sangirsch en Bulusch de Pĕpět, het Bataksch en Bisaya $o$, het Tagalog de $i$ heeft, enz. Bijv. ammay, rijst, Sang. ĕme, Bis. homa y, Bat. ome; tallú, Bis. tolú, Sang. en Bug. tëllu, Bat. tolu, O. en N. Jav. tělu; baggát, Mongondousch bogat, Bis. bọgás, Tag. bigás, Bug. běrĕ, Mal. bĕras, O. J. wwas (uit wŏas, dit uit wĕas), Day. bĕhas, Mak. bérasa, Sideïsch Formosaansch pchag; tangngá, Bis. tongá, Tag. tingá, Mal. en Jav. tĕngah. Staat een aan de Jav. Pĕpĕt beantwoordende klank in de slotlettergreep van een woord, dan heeft in 't Ib. evenmin

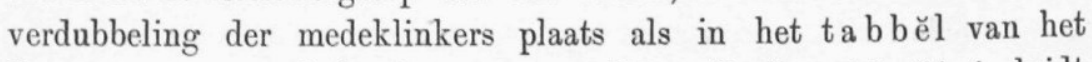
Jayapatra; men vindt dan eene $o$. Bijv. O. Jav. tĕpĕt ${ }^{1}$ luidt in het Ibanag tappót, doch hiervan afgeleid wordt tatappattan, vormelijk $=0$. Jav. tatĕpĕtan, dat in 't Jayapatra juist als in 't Ibanag zou geschreven worden tatappattan; de afwisseling der klinkers $o$ en $a$ op zich zelf reeds wijst op eenen derden klank waaruit zich hier èn $a$ èn $o$ ontwikkeld hebben. De vraag of een dubbele medeklinker van dezen aard in 't O. Jav. ooit de volle waarde van tweemaal den enkelen gehad heeft, zou ik geneigd zijn ontkennend te beantwoorden, want het is zeker, dat het woord hetwelk in 't Jayapatra gespeld wordt a nak-abbi, vrouw, in de gedichten en elders onveranderlijk geschreven wordt a nakbi, en schier zonder uitzondering uitgesproken als a nakĕbi met vier korte lettergrepen, hetgeen onmogelijk ware indien abbi eenen

1 Of zoo men wil tĕpöt; in allen gevalle met eene gerekte slotlettergreep. 
echten dubbelen medeklinker had; immers de voorlaatste lettergreep zou dan positione lang wezen.

Eindelijk vinden wij, zooals gezegd, sluitletters verdubbeld vóór suffixen, geheel op Nieuwjav. en Bulusche ${ }^{1}$ wijze. Bijv. kumonnakĕn KO. V; panunggallan, bevallig afwisselende met panunggalan in IX; mĕttuakan, tinulussakan, kinabaihhan, pamasangngan, dinamakkan, paranakkan in IX; kumonnakan, manurunnakan in $X V$; humarĕppakan, linandĕssakan in XXIV; lampahhakĕn in XVIII; ungsirrĕn in VII.

Het is voor ons, die de uitspraak der oude taal slechts bij benadering kunnen opmaken, moeielijk te beslissen welke van beide schrijfwijzen : kumonakĕn of kumonnakĕn, tunggalan of tungallan, enz. de voorkeur verdient: de getuigen die wij oproepen spreken elkander tegen. Het is trouwens zeer wel denkbaar dat er geen volkomen eenparigheid van uitspraak heerschte. Er is hierbij vooral niet uit het oog te verliezen dat de zooeven behandelde gevallen van verdubbeling, hetzij dan door de uitspraak gewettigd of niet, nooit eenen etymologischen grond hebben, want zoodra ten gevolge van bijzondere omstandigheden dezelfde medeklinker tweemaal zou moeten uitgesproken worden, blijft er slechts één over; dus wordt anak + ku steeds anaku; zoo ook in enkele ontleende woorden, als sĕnâha voor sannâha. Wij zien dus dat verdubbeling achterwege blijft waar ze op grond der etymologie verklaarbaar zou wezen, en dit strekt niet om ons vertrouwen in de juistheid der verdubbeling waar ze geen zichtbare oorzaak heeft en betrekkelijk zelden aangewend wordt te vermeerderen. De nieuwe taal - het is reeds opgemerkt - maakt een overdadig gebruik van verdubbeling, in die mate, dat zelfs de schuchterste Europeesche uitgevers van teksten naar vereenvoudiging in de meest gebruikelijke inlandsche spelling gestreefd hebben.

Een vaste regel is het, dat wanneer eene sluitende $n$ door 't aanhechtsel nya gevolgd wordt, ééne $n$ wegvalt; dus ngaran + nya wordt ngaranya.

$V$ ereeniging van verschillende medeklinkers. Twee verschillende medeklinkers worden aan 't begin eener lettergreep niet geduld, tenzij 10. de laatste er van eene $r, l$ of halfklinker is; bijv.

1 Volgens de meest gebruikelijke spelling wordt in 't Bulusch elke sluitende stammedeklinker, behalve $n g$, verdubbeld vóór de suffixen an en $\breve{e} n$; bijv. kinawutwuttan; kinaliurran; kinarĕpessan; ilekkĕn ; maar linampangan. 
kral, pring, mrâk, dlâha, wlas, gyat, twas; of 20 . de eerste een neusklank is; bijv. ngkâ, ndak, ntou, mpu. Vreemde woorden onttrekken zich aan dezen regel; bijv. kṣatriya, kṣiti, stuti, strî, smara, sangkṣepa, sûkṣma e. a., doch niet zelden worden ook dergelijke woorden $\mathrm{min}$ of meer in overeenstemming gebracht met het Jav. taaleigen, vooral in afleidingen. Men wijzigt gaarne hun vorm ò door den eersten der verbonden medeklinkers te laten wegvallen, òf door 't voorslaan van eene $a$, ten gevolge waarvan de eerste medeklinker niet meer de lettergreep opent, maar sluiter wordt van de voorgaande. Aldus: sangṣipta voor sangkṣipta; sangtabya voor kṣantawya; van stuti, stawa komen de afleidingen mangastuti, pangastawa; van kṣamâ komt angakṣamâ; voor sangskâra zegt men sangaskâra ${ }^{1}$. De nieuwe taal handelt in den geest der oude, gaat alleen met grooter consequentie te werk, met te

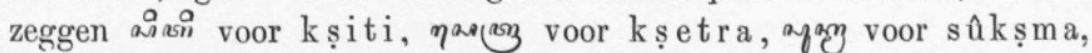

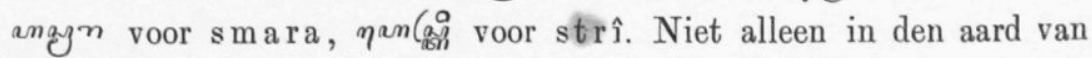
het Javaansch, maar van de geheele taalfamilie ligt het, dat eene opeenhooping van medeklinkers, met de boven vermelde beperking, vermeden wordt. Bijv. O. J. sangtabya vindt zijne wederga iu Tag. sangtabi, Bat. santabi; Jav. estri in Mal. istri; Skr. kṣaya wordt in het Tag. aksaya in de afleidingen inaksaya, magakșaya, enz.; kṣatriya levert in 't Maleisch op tjatriya of kasatăriya.

Klankverplaatsing. De aanwezigheid van zekere medeklinkers in een woord kan teweegbrengen, dat zij onderling van plaats verwisselen. Regelmatig geschiedt dit in het Bataksch (zie v. d. Tuuk Tob. Spr. bl. 53, vgg); in 't Oudjav. vertoont zich zulk eene verplaatsing nu en dan, het duidelijkst in vreemde woorden; bijv. anarawata voor Skr. anawarata; rinangkuça voor Skr. niraṅkuça. In de nieuwere taal, gelijk ook in 't Maleisch, zijn de voorbeelden bijna even talrijk als in het Bataksch; bij degene die reeds vermeld zijn door v. d. Tuuk t. a. p. kan men nog voegen Mal. mardahika, Skr. maharddhika; Jav. Ğ

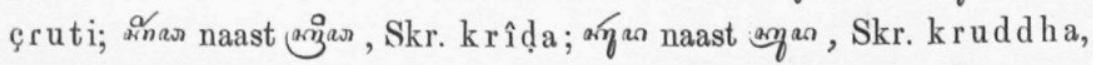
krodha; ó qas, Skr. nyagrodha. Evenzoo in het Tagalog:

1. Of de voorslag van $a$ in afleidingen van lor, bijv. mangalor, thans nog

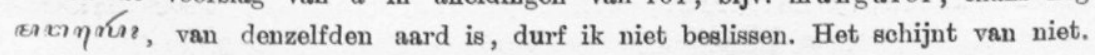


mahaḍlika (ouder mahardika); halagá (ouder haraga) Skr. argha; ook Bis. halaga. Onder gelijke voorwaarden houdt het Tag. ook bij inheemsche woorden veel van zulk eene omzetting, evenals het Bataksch; dus van hibas, siliḍ (silir), tiḍis komen met het aanhechtsel an: hisban, siḍlan, tisdan; van habilin: habinlan (voor habilěnan, habinĕlan). Niet anders in 't Bisaya, bijv. luḍhan van luhuḍ; udlan van ulod. Ook het Dayaksch deelt dezelfde neiging; dus haritan naast rahitan; rahusan naast harusan; rahian naast harian; harias of rahias; hariman of rahiman. Het schijnt dat de aanwezigheid van eene $h$ behalve die van een triller de neiging tot omzetting schier onweerstaanbaar maakt. Een zeker voorbeeld van omzetting in het Bulusch levert barena (warena), banier, voor banera, uit het Spaansche bandera; Sangirsch insgelijks baneha (waarin $h$ ontstaan is uit een brauwend uitgesproken $r$.)

Over 't algemeen is klankverplaatsing in de geheele MaleischPolynesische taalfamilie niets zeldzaams, vooral van nasalen en $r$, $l$ en $s$. Doch zulke omzettingen zijn niet altijd bij de geheele spaakmakende gemeente doorgedrongen en worden dan als slordigheden afgekeurd. In het Samoaansch hoort men mānu, reuk, voor het juistere nāmu; lawa'au, roepen, voor wala'au (zie Pratt, Sam. Gramm. 2 ed. p. 2). Een goed voorbeeld van omzetting levert Maori ngaro, vlieg, naast rango, Mal., Tag., Bis., Day. langau enz.

Uitstooting. Eene $h$ wordt een enkele maal tusschen twee klinkers uitgestooten; bijv. tatanpatanggwa "zonder dat het zal kunnen verhinderd worden", voor otangguha Râm. 103. Vgl. de gevallen van uitstooting bij uitwendigen Sandhi in 't volgende hoofdstuk.

Bij deze gelegenheid zij opgemerkt dat, geheel onafhankelijk van den Sandhi, enkele woorden in de HSS. nu eens met, dan weêr zonder sluitende $h$ geschreven worden; o. a. lumrâ BY. 2; 53; 95 ; waar de var. l overal lumrah heeft; thans uitsluitend ryखु? Voorts rapu, var. l rapuh BY. 52; 56; ontwijfelbaar rapuh

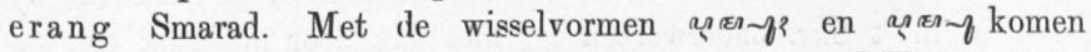
overeen rĕmpuh Arj. Wiw. 202; 259; en rěmpû BY. 52; 632; 64l. Voor 't oudere sisî zegt men thans aisi? Vermoedelijk gingen deze en soortgelijke woorden met dubbelen vorm oorspronkelijk uit op eenen gutturalen triller, die, gelijk men weet, gewoonlijk geen spoor in 't O.Jav. achtergelaten heeft dan dat de voorgaande klinker lang werd. In enkele gevallen evenwel schijnt die klank in 5e Volgr. IV. 
$h$ overgaan te zijn, zooals in $\mathrm{wahu}$, nieuw ${ }^{1}$; Nademaal in 't Dayaksch, Bulusch, Sangirsch, Balineesch de bedoelde klank eene $h$ geworden is, zou men ook in 't Jav. de vormen met $h$ voor juist, hoewel tevens voor eigenlijk gewestelijk, mogen houden. Intusschen mag niet verzwegen worden dat tegenover wahu en bahĕm het Maleisch in baharu en garham eene $h$ vertoont, en in de veelvuldig voorkomende plaatsnamen $\mathrm{W}$ aharu en $\mathrm{W}$ arahu, eigenlijk "nieuw" beteekenende, ook eene $h$ voorkomt. Dit gevoegd bij de omstandigheid dat behalve wahu zoo dikwijls wâh u geschreven staat, wekt het vermoeden dat de Oudjav. vormen des woords eigenlijk ontstaan zijn uit wa'h u, wisselvorm wah'u, in welk geval de $h$ niet de platsvervangster van eenen anderen triller zou wezen.

Onjavaansche Sandhiregelen. Tengevolge der overname van verscheidene Sanskritwoorden in hun oorspronkelijke spelling, en deels ook misschien tengevolge van navolgingszucht, heeft men sommige Sandhiregelen van 't Skr. toegepast op Javaansche woorden, waarvoor die regelen niet bestemd waren en volstrekt niet deugden. Zoo wordt de $n$ in eene n veranderd wanneer er een $r$-klank vooraf gaat; bijv. reṇa, rĕṇĕk, parṇṇah. Indien deze schrijfwijze in den aard der taal gelegen had, zou men ook turuna, tirunĕn, marani enz. enz. geschreven hebben, hetgeen men evenwel niet deed.

Nog meer in strijd met het wezen van 't Javaansch is het gebruik van ș instede van $s$ na een anderen klinker dan $\overline{\bar{a}}$ bij inheemsche woorden, als $n$ ûșa, naar 't model van manuṣa. Niet zelden schijnt men s, alsook c gebezigd te hebben om op een erkend uitheemsch woord den stempel van 't Skr. te drukken, bijv. in raṣa, averechts voor rasa, wellicht naar 't model van roșa; çakula voor sakula KO.I naar 't voorbeeld van çakuna; diwaça voor diwasa, alsof het iets gemeen had met kawaça. Dezelfde wanspelling ontmoet ons nu en dan bij echt Jav. woorden, bijv. suçuk, suçukan, çuçukan, alle drie in KO.I, naar 't model misschien van çoka, açoka. ${ }^{2}$ De slotsom is dat de regelen waaraan 't gebruik van $s$, s. en $\xi$ in 't Skr. onderworpen is, niet dan door misbruik ook op

1 De $h$ werd als zoodanig uitgesproken; ware dat niet het geval geweest, dan zou het woord onvermijdelijk tot wo samengetrokken zijn.

2 Zulke wanspellingen, hoe verkeerd ook, zijn niet half zoo dwaas als 't Engelsohe island naar 't model van isle, waarmede het niets te maken heeft; of could, naar gewaande analogie van should en would; of seythe, dat ons zicht is, om het in symmetrie te brengen met de Seythen, of wie weet waarom. 
Maleisch-Polynesische woorden zijn toegepast, en wel zeer onvolledig. De gesprokene taal bezat slechts éne $s$, gelijk thans.

\section{HOOFDSTUK II.}

\section{SANDHI IN DEN volzIN (uitwendige Sandhi).}

De veranderingen welke de klanken bij uitwendigen Sandhi ondergaan, zijn nagenoeg dezelfde als bij inwendigen Sandhi, voor zooverre de regelen toegepast worden, doch juist ten opzichte der meerdere of mindere vrijheid dier toepassing vertoonen de teksten een aanmerkelijk verschil. Zoo kan men opmerken, dat in het stelsel der meeste dichtwerken volstrekt geen hiaat in een pâda geduld wordt, terwijl het Râmâyaṇa den hiaat volstrekt niet schuwt en dien niet enkel na eene kortere of langere pauze toestaat. Van het literarisch proza van 't Âdiparwan geldt hetzelfde als van 't Râmâyana. Wat eindelijk de oorkonden en andere inscripties aangaat, zijn de gevallen van hiaat talrijker dan die van Sandhi. Alleen daar waar twee zinsbestanddeelen onderling zeer nauw verbonden zijn, als het ware eene samengestelde uitdrukking vormen, passen alle geschriften schier zonder uitzondering de regelen toe; saka ing wordt overal sakeng; mara i wordt mare. De aard en wijze der klankovergangen is in alle stukken dezelfde en ligt derhalve in het wezen van 't Oudjavaansch; de uitbreiding van den regel tot gevallen waar de klankverandering mogelijk, maar niet noodzakelijk is, mag beschouwd worden als een teeken van literarische verfijning.

De voorbeelden die men in de volgende bladzijden zal aantreffen, zijn bij voorkeur gekozen uit de oorkonden en het proza van het Âdiparwan, omdat de daarin gevolgde regelen van klankovergang à fortiori van kracht zijn in dichtwerken. Wegens de overeenkomst in aard tusschen de regelen bij inwendigen en uitwendigen Sandhi meen ik in dit hoofdstuk met eene kleinere keur van voorbeelden te kunnen volstaan.

\section{§. 1. Kuinkers.}

Twee gelijkslachtige klinkers, wạarvan de eerste sluiter, de tweede beginletter van een woord is, smelten samen tot eenen 
langen. Bijv. mangkanâbhiprâya nira voor mangkana abhiprâya; kakî Ngadulĕngĕn voor kaki i Ngao KO. V; thânî si J. voor thâni i si J., ib.; Pâttarâsangga voor $\mathrm{Pu}$ Uttarâsangga; XVII.

Volgens de meest gewone schrijfwijze der oorkonden heeft er in dit geval geen Sandhi plaats, wordt de klankverandering ten minste door het schrift niet aangeduid; bijv. ikana alas KO. L: haji i Warahu VII. Het is twijfelachtig of deze laatste manier van schrijven meer aan de heerschende uitspraak beantwoord heeft dan de andere, en of ze niet als eene etymologische spelling moet beschouwd worden. In allen gevalle vinden wij den zooeven gestelden regel terug in 't Samoaansch. Wanneer namelijk in deze taal twee gelijkslachtige klinkers samenkomen bij 't vormen van samengestelde uitdrukkingen of als sluit- en beginletter van twee op elkaar volgende woorden, die in nauw onderling verband staan, dan smelten ze samen tot eenen langen. Dus matâlofa, vriendelijk kijkende, uit mata en alofa; matâitu, een Anitublik hebbende, uit mata en aitu: 1 alofâtu uit alofa en atu (vgl. Pratt Gramm. Samoan Lang., $2^{\mathrm{d}}$ ed. p. 2.)

De a, kort of lang, smelt met $\mathbf{i}$ samen tot $\mathbf{e}$; met $\mathbf{u}$ tot $\mathbf{0}$; met $\boldsymbol{\theta}$ tot $\boldsymbol{\theta}$; met $\mathbf{0}$ tot $\mathbf{0}$. Bijv. sangkerikâ uit sangka irikâ KO. XVI; tekang uit ta en ikang V, VII; wargge dalĕm uit wargga i dalĕm II; moghakneng wilantih voor moghakna ing w; kapagute luñeip voor kapaguta i luñcip VII. - Eene spelling als tkâ i KO. I is zoo uitermate zeldzaam, zelfs in de oorkonden, dat men geneigd zou wezen ze toe te schrijven aan eene verwarring met het gelijkwaardige tkâ ri, of anders voor een offer an de etymologie te houden. Eenvoudig eene spelfout is yataikana uit yata ikana KO. IX; in den tijd van bedoeld stuk sprak men het teeken voor ai (eigenlijk âi) bereids als $e$ uit; van daar de verwarring.

In het Pampanga geldt bij nauw verbonden woorden dezelfde regel als in 't Oudj., zoodat bijv. $\mathrm{ka}$ in i wordt keni; iya en ini geeft iyeni; tula ita wordt tuleta.

Een voorbeeld dat $\frac{u}{a}$ met $o$ overgaat in $o$ is tikomaritrânâna Âdip. Uit $a$ met $e$ wordt $e$, bijv. Pâṇ ḍa wẽ̃ing voor Pânḍawa eñjing BY. 95; uit $a$ met $o$ natuurlijk $o$, dewijl de taal geen $a u$

1 De opgave dat mataitu bestaat uit mata, $a$ en aitu in 't Sam. Wdb. van Pratt i. v. is onjuist. 
meer kent; dus ling nirojar uit nira ojar BY. 253. Het Samoaansch trekt $a$ met $u$ niet samen, maar wel $a$ met korte $o$ tot lange $\hat{o}$; bijv. ma on a wordt môna.

Korte of lange $\mathbf{i}$ gaat vóór een ongelijkslachtigen klinker in $\mathbf{y}$, of anders in iy over; bijv. diwasa ny âjñâ KO. V; II; e. e. Uitzonderingen hierop zijn in de oorkonden niet zeldzaam; o. a. KO. I schrijft ni Ayâ, ni Uḍuh, si Angguh, doch daar dezelfde ook kady anggâ heeft, ligt de eerste spelling onder verdenking van zuiver etymologisch te zijn. Overgang in iy komt vooral in gedichten en dan nog betrekkelijk zelden voor; bijv. riy anak Râm. 125; lihatiy ari-nta BK. 106; adhipatiy Ugrasena 169.

Korte of lange $\mathbf{u}$, alsook $\ddot{\boldsymbol{0}}$ en $\mathbf{0}$ (uit a u) worden vóór een ongelijkslachtigen klinker w. Bijv. munggw i van munggu; aturw ing van aturû Âdip.; karĕngw ing van karĕngö BY. 644. Bij overgang van $o$ in $w$ valt op te merken, dat dan de volgende klinker verlengd wordt; dus y an kw âw ĕdi voor ko aw ědi BY 477; mangilu âkrak voor mangilo akrak Sutas. fol. 25 , a. 1

In het Pampanga valt $o(=$ Oudj. $u)$ vóór een volgende $i$ uit, bijv. tot'ita voor toto ita. Evenzoo in 't Samoaansch, in afleidingen; dus tosina voor tosoina. Zulk eene uitstooting veronderstelt een ouder standpunt, waarop de $u(\breve{o})$ wel reeds tot $w$ verzwakt, maar nog niet geheel verdwenen was, en is in wezen één met den Nieuwjav. regel volgens welken ri, lir ontstaan is uit rwi, lwir.

De uit een tweeklank ontstane e herneemt, of liever behoudt, vóór eenen klinker hare oudere gedaante; bijv. asuway atihang BY. 553; sakatambay eñjing, sakatambay esuk, doch sakatambe suk Âdip. Afwijkingen van den regel komen in de Oorkonden hier en daar voor; bijv. bale inantun KO. V.

In aard komt de Oudj. regel aangaande $\boldsymbol{\theta}$ overeen met dien in 't I banag en Pampanga; zie bij Hoofdstuk I. Anders is het Samoaansch gebruik; want dit laat eene $e$ vóór eenen volgenden klinker wegvallen; dus awe atu wordt aw atu. De reeks van klankovergangen die tot dezen toestand geleid heeft, bevat, theoretisch, de volgende termen: awe awi, awy, aw' (met Russische Jer'), waaruit eindelijk a w.

1 Mer vergelijke Pali sw â yam uit so a ya mạ e. dgl. Een historisoh verband tusschen de gelijke versohijnselen in 't Pali en 't Oudj. bestast er natuurlijk niet. 


\section{§ 2. MEDEKLINKERS.}

Anuswâra en Wisarga. Deze teekens hebben de volle waarde van eenen medeklinker die de lettergreep sluit. Staan zij vóór een woord dat met eenen klinker begint, dan gaan zij over in $n g(a r)$ en $h$ $(a n)$, hetgeen op de uitspraak geen anderen invloed heeft dan dat zij van sluiters beginletters worden. Hierbij valt op te merken, dat an en an, overal waar ze in een woord of vóór een enklitisch woordje van een medeklinker gevolgd zijn, beschouwd moeten worden als beginletters eener lettergreep. Dus bestaan bijv. mangkâ en ahning uit de lettergrepen ma en $\mathrm{ngkâ} ; a$ en $\mathrm{hning}$, andere uitspraak van hĕning. Deze eigenaardige uitspraak, zoo geheel afwijkende van de onze, is echt Javaansch; van daar het bekende feit, dat een voorlaatste lettergreep waarop een neusklank met medeklinker volgt open is, en niet gesloten, zooals in onze taal; zie de voorbeelden bij Roorda, Jav. Gramm. $§ 42$, en voeg er bij ๆcṁıas, ontstaan uit b â-ngsa. Skr. waṃça, met rekking der $a$, daar deze in eene opene lettergreep staat. Strikt genomen is de nieuwe Jav.

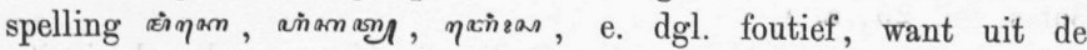
juiste uitspraak, blijkt dat de taal geen sluitende nasaal bedoelt. Een ander bewijs dat in 't Javaansch, oud en nieuw, de van een medeklinker gevolgde nasaal eene lettergreep begint, ligt in voorbeelden als $\mathrm{ngkâ}, \mathrm{nggon}, \mathrm{ndan}$, enz., die in onze taal niet kunnen voorkomen, omdat wij de lettergreep wèl met eene nasaal sluiten. Evenals in 't Jav. is het in het Fidjisch, in zoover ook in deze taal $m b, n d, n g g, n g k$ met elkaar verbonden eene lettergreep beginuen. ${ }^{1}$

Media en tenuis. In tegenstelling tot het Maleisch, Bataksch, Dayaksch, alsook tot het Sanskrit en Nederlandsch, pleegt het Oudj. eene sluitende media niet tot eene tenuis te verscherpen. Wel vindt men enkele dubbelvormen, met eenigszins gewijzigde beteekenis, van één en hetzelfde woord, zooals lod, zee, en lor, Noord, waaruit

1) De Jav. en Fidjische uitspraak is ontegenzeggelijk moeielijker dan de onze; en daaruit laat zich gereedelijk verklaren dat zooveel Maleisch-Polyn. talen de nasaal in bedoeld geval geheel hebben laten verdwijnen. Zulks gesohiedt in alle Polynesische dialekten, bijv. Maori whaka, Sam. wa'a, terwijl Fidji nog wangka zegt; Maori take, doch Makassaarsoh tangke, Sund. tangkay. Een begin van verwaarloozing der nasaal vertoont zich in 't Nieuwj. in $\mathrm{ka}$ voor $\mathrm{ngka}$; dan voor ndan. Het Bug. vertoont iets dergelijks, bijv. in takke voor 't zooeven vermelde tangke. Het Ibanag eindelijk heeft elke nasaal + medeklinker vervangen door verdubbeling. 
men zou mogen opmaken dat er in overouden tijd reeds nu eens een dentaal, dan weer een linguaal aan 't einde gehoord werd, en dat uit de laatste door verzachting eene $r$ ontstaan is, doch zulk een overgang is niet beperkt tot de d als sluitletter en kan dus niet in verband staan met eenigen Sandhiregel. In het huidige Javaansch wordt elke sluitende media als tenuis uitgesproken, doch vóór aanhechtsels komt de oorspronkelijk media weder voor den dag, volmakkt dus gelijk in onze taal en het Sanskrit. Slechts in enkele woorden is de media voor goed tenuis geworden, hoewel er dan nog meestal bijvormen met media bestaan; bijv. nseranl, oudstijds la-

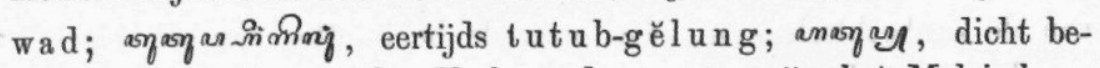
zet, voor atub, atĕb. Veel verder gegaan zijn het Maleisch en Dayaksch, want in deze talen keert de uit eene media verloopen tenuis vóór den klinker eens uitgangs niet meer tot den ouden toestand terug. De talen van de Filippijnen en Noord-Celebes komen te dezen opzichte in hoofdzaak met het Oudj. overeen.

Eene tenuis blijft voor de beginmedia van een volgend woord onveranderd; afwijkingen hiervan, als pad-blas, veertien, Adip.; a d wulati voor at w. Râm. 194 zijn betrekkelijk zeldzaam.

Overgang van neusklanken in eene andere klasse. Van de nasalen is de dentale $n$, inzonderheid van sommige rededeeltjes, de eenige die vóór eene palataal in $\tilde{\mathrm{n}}$, en vóór eene cacuminaal in $\underset{n}{n}$ pleegt over te gaan. Bijv. y a ñcampur bestaat uit de twee woorden yan en campur; deñcacah uit den en cacah; yạ̣ḍtĕng uit yan en ḍtĕng; tĕkwaṇ-ḍ̆ěngö uit tĕkwan en ḍ̆ngö (d. i. zonder voorafgaande nasaal : r ĕng g̈); zoo ook in samenstellingen als tañcala, onbewegelijk ${ }^{1}$, en samengestelde uitdrukkingen als wang unḍa hin a Râm. 155. Vóór eene lipletter blijft de $n$ steeds onveranderd, zelfs wanneer $\mathrm{t}$ an aan ons "on"-beantwoordt, en bij andere partikels die met het volgende woord eene samengestelde uitdrukking vormen; dus zegt men anpaçabda, yanpanusuk, tanpanolih. Vó́r eene lipletter bewaart de nasaal dus steeds het karakter van een sluitletter; van daar dat het Jav. thans nog heeft tanpa, dat wel is waar als

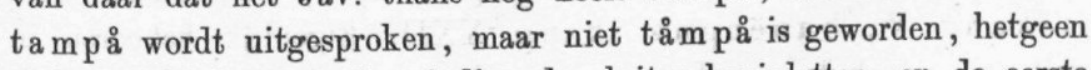
toch geschied zon zijn, indien de sluiter beginletter, en de eerste lettergreep dus eene opene geworden was. Niettemin moet erkend

1 Hierbij behoort ook tangeh of tangheh, A.W. 172; 283 ; 315 ; naast tanngeh, BY. 27; $109 ; 671$, Over de vereenvoudiging van tangngeh tot tangeh gie hieronder, 
worden dat de tegenwoordige uitspraak tampå eenen overgang der $n$ tot de klasse der lipletters vertoont, en dat het bekende on $\tilde{n n}^{2}$ moeielijk anders te verklaren is dan als eene verbastering van tanwruh. Misschien is ook het oude tambis, bijna, eene samenkoppeling van $\tan$, niet, en wis $=$ wus.

Behoudens enkele uitzonderingen, die niet eens boven allen twijfel verheven zijn, blijft dan in 't Jav. eene sluitende $n$ alleen voór lipletters onveranderd. Het Bulusch kent deze inconsequentie niet, want in deze taal richt zich een neusklank, hetzij oorspronkelijk Anuswâra of dentale $n$ van partikels, en bij inwendigen Sandhi ook van de aanhechtsels -an, -ĕn, naar de beginletter van het volgende woord, tenzij dit mo of $\mathrm{mu}, \mathrm{miyo}, \mathrm{mai}$ is. De neusklank wordt dus $m$ vóór lipletters, $n$ vóór $d$ en $t$ (dentaal of supradentaal), $n g$ voór gutturalen, en afwijkend van 't Jav. $n$ vóór klinkers ${ }^{1}$ en $s$. Dus kan pe wordt kampe; ung kaure voor um kaure. Door invloed der nasaal gaat dan eene $w$ tevens in $b$ over; bijv. a $\mathrm{m}$ bĕngi voor a ̣̣ of an wĕngi (vgl. Niemann Bijdr. 43 en 90, waar echter de nasaallooze vormen als de oorspronkelijke worden beschouwd). Zou er een dubbele medeklinker ontstaan, doordat een woord met $m$ of $n g$ begint, dan wordt de dubbele, geheel op Oudjav. manier, waarover straks nader, vereenvoudigd; dus u munte voor um munte; u ngaran voor ung ngaran. Wat mo en mu betreft, van deze enklitische woordjes richt zich de $m$ naar den voorgaanden sluiter; bijv. wiwittĕnno voor wiwittĕnmo; wunuĕnnu voor wunuĕnmu (vgl. Niemann Bijdr. 88; 99). De geschiedenis van dit verschijnsel is waarschijnlijk deze, dat de $m$ hier eerst, gelijk in zooveel talen van de Stille Zuidzee, is overgegaan in eenen klank die het midden houdt tusschen $m$ en $w$, daarna in $w$, eenen klank, zwak genoeg om aan den voorgaanden medeklinker gelijk gemaakt te worden.

Verdubbeling. Verdubbeling van medeklinkers kan onder dezelfde omstandigheden als bij inwendigen Sandhi plaats hebben. Bijv. ingng umah KO. X; ikanangng uangI; kumonnakĕnn irikang V; kunĕngng ikang XXII. Eigenlijk behooren in zulk een geval de woorden aaneengeschreven te worden, hetgeen ik alleen om wille der duidelijkheid nagelaten heb. De $n$ wordt ook in de gedichten niet zelden om de maat verdubbeld; bijv. pa p a g a k ĕn n

1 Dat in 't Bul. $n$ vóór klinkers uit Anuswâra kan gesproten zijn, ziet men o. a. uit sana-, Pakewasch sanga, in sanaawu, echtgenooten, eig. haardgenooten. 
aku Râm. 131 ; apann aku 153; nahann ikana, en lawann a ri 154. Daarentegen hebben de HSS. van dit gedicht iu plaats van $\mathrm{ngng}$, waar de maat eene lange lettergreep eischt, doorgaans het rustteeken; bijv. wwang umulat $96 ; 118$; kumbang u mandĕl 69. Aangezien in dergelijke gevallen van eene pauze geen sprake kan wezen, dient het teeken vermoedelijk slechts om eene gerekte uitspraak der lettergreep aan te duiden, hetgeen anders door verdubbeling der medeklinkers of bij beklemtoonde lettergrepen door verlenging der klinkers geschiedt

Schrijfwijzen als ryy Ayodhyâ; mojar tta; bwat thaji; at thana, e. dgl. zijn niet anders dan uit navolgingszucht geboren wanspellingen.

In het Ibanag mogen alle sluitende medeklinkers behalve $d$ vóór klinkers verdubbeld worden; bijv. dakall ak, ik ben groot, uit dakal en ak (de Cuevas p. 9).

Vereenvoudiging. Eindigt een woord op een medeklinker en begint het volgende met denzelfden, dan wordt de zoo ontstane dubbelconsonant vereenvoudigd, evenals bij inwendigen Sandhi. Dus tlasinurat voor tlas sinurat KO. II; lawasang voor lawas sang, ib.; tlasuddha voor tlas suddha XXII. Intusschen is de etymologische spelling, bijv. malaw as sira Râm. 20 , geenszins uitgesloten.

Voorbeelden van vereenvoudiging in 't Bulusch zijn hierboven reeds gegeven; men kan er bijvoegen u londei voor ul londei; a nuwu voor an nuwu. In tegenstelling tot het Jav. wordt namelijk in 't Bulusch een Anuswâra aan eene volgende $l, m, n$, en oorspronkelijke $r$, geassimileerd en daarna de dubbele' medeklinker vereenvoudigd, Dit geschiedt ook bij inwendigen Sandhi; dus van lulun wordt met prefix mem (mĕng), d.i. 0. mang, afgeleid mĕlulun, voor mĕllulun. ${ }^{1}$ Ook in 't Dayaksch wordt de sluitende neusklauk der prefixen mang ( $\mathrm{ma} m$ ) en in of i m geassimileerd aan $l, r$, daarenboven aan $h$ en soms aan $s^{2}$, en de zoo ontstane dubbelmedeklinker vereenvoudigd. Evenzoo in 't Maleisch vóór $l, m, n, r, h$; bijv. mălăpaskan staat vóór măllăpaskan, en dit bevat het prefix ma ṃ (măng). (Vgl. Pijnappel Spr. §37). In het Ibanag wordt de nasaal aan alle volgende klinkers geassimileerd, doch de dubbele blijft verder onveranderd; dus nat tolay

\footnotetext{
1 Ten onrechte wordt in Niemanns Bijdrage bl. 50 bedoeld suffix als mẽ opgegeven.

2 Verkeerd voorgesteld bij Hardeland bl. 41 .
} 
voor nan (nang) tolay ${ }^{1}$. Wat de nasaal van 't prefix ma m (mang) aangaat, die assimileert zich aan een $l, m$ en $n$; dus van labbok komt mallabbok; van nabu: mannabu. Vgl. de Cuevas p. 92 , vlg.

Uitstooting. Wanneer de sluitende $h$ van een woord gevolgd wordt door den klinker van een woordje dat met het voorgaande in naw verband staat, zoodat er als het ware eene samengestelde uitdrukking ontstaat, dan valt ze soms spoorloos uit, en wordt de daardoor ontstane hiaat op de gewone wijze-opgeheven. Bijv. alunggw ing çayana voor alungguh ing; tanseng voor tansah ing; tanwring voor tanwruh ing. Dit laatste voorbeeld moet rechtstreeks uil tanwrw ing ontstaan zijn, zoodat ook de $w$ is weggevallen, op dezelfde wijze als in 't Nieuwjav. uit het oudere rwi, lwir, pamwit geworden is ri, lir, pamit; men vergelijke ook

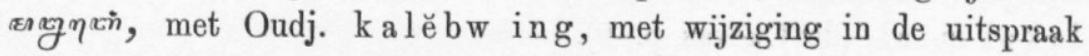
van obing tot obeng, gelijk ook voorkomt in ø̇ $\eta \dot{m}=\dot{y} \dot{m}$, uit $\mathrm{mung} g \mathrm{w}$ ing.

1 Cuevas (Arte p. 15) beschouwt de vormen zonder nasaal als de oorspronkelijke, doch dan zou de dubbelmedeklinker geen reden van bestaan hebben. Daarenboven is nat tolay klaarblijkelijk hetzelfde als Tag. nang tauo; tat tolay = Bis. sang tauo; it tolay = Bis. ing tauo; daargelaten dat tolay en tauo etymologisch verschillen. 